\title{
Determinants of Micro and Small Enterprises Growth: The Case of Durame Town, Kembata Tembaro Zone, Southern Nations and Nationalities and Peoples Region, Ethiopia, 2016
}

\author{
Dagmawit Alemayehu, Yishak Gecho \\ Rural Development and Agricultural Extension Department, Wolaita Sodo Univeristy, Wolaita Sodo Ethiopia
}

Email address:

alexdagmawit22@gmail.com (D. Alemayehu),yishakgecho@yahoo.com (Y. Gecho)

To cite this article:

Dagmawit Alemayehu, Yishak Gecho. Determinants of Micro and Small Enterprises Growth: The Case of Durame Town, Kembata Tembaro Zone, Southern Nations and Nationalities and Peoples Region, Ethiopia, 2016. International Journal of Business and Economics Research. Vol. 5, No. 5, 2016, pp. 161-175. doi: 10.11648/j.ijber.20160505.15

Received: August 16, 2016; Accepted: August 31, 2016; Published: October 14, 2016

\begin{abstract}
This study was conducted in Durame Town, KembataTemaro zone, Southern Ethiopia. The objective of the study is to find out factors that determine growth of Micro and Small Enterprises and to assess current status of Micro and Small Enterprises in terms of employment and capital growth. Out of 148 Micro and Small Enterprises in the study area, 100 Micro and Small Enterprises (MSEs) were selected as a sample using stratified and simple random sampling technique. They were stratified based on the sector they are operating. The data were analyzed using descriptive statistical tools including mean, percentage and standard deviation. The binary logit model was applied to identify determinants of MSEs growth. The study used employment and capital as growth indicators. Growth rate for the two indicators was computed by the change of natural logarithm of employment or capita over the life of enterprise. After calculating growth rate, Micro and Small Enterprises were grouped into two categories growing and non growing. Micro and Small Enterprises which had growth rate $<0$ categorized into non growing and Micro and Small Enterprises which had growth rate $\geq 0$.The finding of the study shows that out of the total sample $40 \%$ of Micro and Small Enterprises are growing and $60 \%$ of Micro and Small Enterprises are non growing in terms of employment. In terms of capital $69 \%$ of Micro and Small Enterprises are growing and $31 \%$ are non growing. The model result indicated that out of 19 explanatory variables, 10 variables were found to be significant in determining Micro and Small Enterprises growth. Factors found to be significant for employment growth were: entrepreneurship training, location of enterprise, motivation of owner, market linkage, access to finance, access to water. Factors found to be significantly influencing capital growth were: education level of owner, motivation of owner, number of owners, initial employment size, social network. Hence, government and non-government organizations that are concerned with the promotion and development of MSEs need to take these factors in to account to accomplish better result and increase the potential contribution of MSEs to the economic growth.
\end{abstract}

Keywords: Micro Enterprise, Small Enterprise, Employment, Capital, Binary Logit, Growth

\section{Introduction}

Poverty in Ethiopia is widespread and remains a major challenge of sustainable development and stability. It is estimated that close to half of the population in urban and rural areas of Ethiopia live in absolute poverty due to lack of economic opportunities, governance crisis, inadequate basic household income and poor means of survival [1].Sources of unemployment has been identified as one of the major challenges facing young people around the world, ranging from $25 \%$ to $45 \%$ in most developing countries. Unemployment rate of youth group in Ethiopia is estimated to be $26.1 \%$ [2].

There are multi dimensional problems like extreme poverty, unemployment, low percapita income, and unequal income distribution facing in many developing countries. As a result, different governments are framing different 
strategies and policies to create job opportunities and to pull these countries out of their problems. One strategy as to create jobs and accommodate maximum number of citizens has been emerged, i.e., the establishment of Micro and Small Enterprises [3]. Government of Ethiopia has issued a national SMEs development strategy for the promotion of Small and Micro Enterprises in 1997 and established a well concerned institution for the sector by the Council of Ministers of Ethiopian Regulation Number 33/1998 on April 3, 1998. The revised MSEs Development Strategy was designed in 2011 in order to integrate the development of the sector with the country's 5 year (2003-2007) Growth and Transformation Plan (GTP), hoped to bring about rapid economic growth and lift up the country to middle income level.

MSE is one of the institutions given recognition in Ethiopia's industry development plan and is the fact that it serves as vehicles for employment opportunities at urban center and as it underpin the economic development. MSE serves as sources for sustainable job opportunities not only for developing countries like Ethiopia, but also for developed countries like USA. Thus they should be given prior attention as they are important and serve for sustainable source of job opportunities to Ethiopia [4]. The country gives priority to these institutions as they are important vehicles for production and growth in the manufacturing sector. They will also be the major productive forces in the manufacturing sectors when effort towards the country's renaissance is over. Japan, for instance, the globally recognized in giant companies like Toyota and Sony more than 50\% manufacturing products are produced by MSE [4].

In Ethiopia, MSEs are the second largest employment generating sector next to agriculture. A National survey conducted by Central Statistics Agency [5] indicates that more than 1.3 million people in the country are engaged in MSE sector.

The promotion of MSEs is one of the strategic directions pursued by the government during the GTP implementation period (2010/11-2014/15), focusing on promoting the development and competitiveness of MSEs. According to Federal Micro and Small Enterprise development agency report during the plan period 2011-2014 the sector was able to generate $6,671,012$ jobs, exceeding the goal set for the total GTP period ( 3 million Jobs), ETB 25.62 billion through Domestic Market linkage, exceeding the goal set for the total GTP period (ETB 10 billion), 65,375,026 USD through Foreign Market linkage, exceeding the goal set for the total GTP period $(46,166,142 \mathrm{USD})$. The success of the strives in the development of sector is also reflected in the transfer of 3,141 MSEs to Medium Enterprises level [6].

Though there is a progress on the contribution of MSEs to the economy, large number of MSEs are eventually closed or stagnated at starting phase. As reports and studies documented, there are internal and external factors which affect the growth of the MSEs such as lack of entrepreneurial skills, poor location of business cites, startup capital, lack of infrastructure, financial access and over emphasis to short term profit are internal and external factors affecting the growth of MESs.

Starting from 1997220 MSEs were established in the study area in five sectors; manufacturing, construction, service, trade and urban agriculture. But only148 MSEs are active currently. The remaining MSEs are not functional. Most of those active MSEs are also not growing. This study focused on identifying those internal and external factors that determine growth of MSEs empirically.

Young people have a hard time in African job markets; with inadequate education and skills and few opportunities, most young Africans face a future of low-wage employment, unemployment and underemployment. An increasing youth population adds to the pool of job seekers every year, worsening the situation. The expansion of employment opportunities is far below the growth in the youth population because of a lack of appropriate technologies and investment [6].

The youth population in Ethiopia is rapidly growing, as it has more than doubled between 1990 and 2007, from 6 million to 13 million [5] and become more than 20 million in 2014.The government of Ethiopia formulated National MSE Development and Promotion Strategy in 1997 and it has been implemented in the past years. The main objective of the strategy is creating industrialists who run the country's development by organizing the educated youth and the youth in general and providing job opportunities to those graduated from university and TVET by developing youth's skill and innovation, perception and improving their saving culture.

Even though MSEs are contributing a lot for poverty alleviation, they are facing multidimensional problems both at start up and operational levels [7]. A large number of MSEs are unable to grow (expand in terms of employment) and remain to be survival (non-growing) type which cannot provide employment [8].Out of 1000 MSEs in Ethiopia around $69 \%$ of them are found survival types [9] and particularly in capital city Addis Ababa majority (75.6\%) of the MSEs are unable to grow at all since start up and only $21.9 \%$ of the MSEs had added workers [10].

The same is true in the study area Durame town administration. Around 220 micro and small enterprises were registered officially starting from 1997 but most of them are not functional currently very few enterprises are performing effectively. Establishment of MSEs alone is not enough it needs detail follow up and assessment Moreover, identifying the growth factors of MSEs is important as it establishes the base for preparing a policy framework and strategy that safeguards the success of MSE operators [1].

Few empirical efforts have been done to study growth of MSEs. The existing knowledge-gap and the focus for the sector development motivated the researcher to analyze empirically factors associated with growth of MSEs in Ethiopia, specifically in southern Ethiopia, Kembata Tembaro Zone, Durame Town administration.

Furthermore, previous studies conducted in Ethiopia focused on national level, the regional level and sub cities of Addis Ababa. So that, this work is designed to fill the research gap of MSEs existed at zonal and district level and 
find out factors specifically affecting growth of MSEs in micro level. MSEs registered in the study area are not effective in their performance so it is vital to investigate the factors that affect the success of micro and small enterprise in Durame town. This study tried to answer the important question of why only few enterprises are successful and why others remain ineffective or non-growing.

\section{Research Methodology}

\subsection{Description of the Study Area}

This study was conducted in Durame town which found in the administrative zone of the Kembata Tembaro Zone, southern Ethiopia. The town has a latitude and longitude of $7^{\circ} 14^{\prime} \mathrm{N} 37^{\circ} 53^{\prime} \mathrm{E}$ with an elevation of 2101 meters above sea level. It is located at a distance of $357 \mathrm{~km}$ in the south-west from capital city of Ethiopia, Addis Ababa and $130 \mathrm{~km}$ from the capital city of the region, Hawassa. It is surrounded by Damboyaworeda, Kachabiraworeda and Kedidagamelaworeda.

According to 2006 report of Administration of Durame Town Finance and Economic Development Durame has a total population of 66857 , of which 29514 are male and 37343 female. The majority of the inhabitants are Protestants which consists $86.51 \%$ of the population, $7.39 \%$ followEthiopian Orthodox Christianity and the remaining $4.93 \%$ are Catholic.

\subsection{Sampling Procedure}

The study was conducted in Durametown, kembata Tembaro zone of southern Ethiopia. The study area has been selected purposively because the area is known by high unemployment rate and the researcher has good knowledge on the area and lives in the study area. According to theoffice data, out of 220 registered MSEs in the town administration only 148 MSEs are currently operating. The remaining MSEs stopped up at the startup period. Therefore, the study focused on the active 148 MSEs. These 148 MSEs have a total of 1235 owners. The unit of analysis for this study is Micro and Small Enterprises. A simplified formula (Yeman formula) as mentioned above has been employed to determine the required sample size. Having the sample size MSEs was stratified into five stratum based on the sector they are operating; Construction (50), Manufacturing (18), Trade (28), Service (39), and urban agriculture (13). Then by using simple random sampling technique 100 MSEs were chosen. They were taken from each stratum with probability proportional to size sampling (PPS).

\subsection{Source and Methods of Data Collection}

Both primary and secondary sources of data were used for this study. The researcher gathered primary data from MSEs through structured questionnaire and unstructured interview to local MSEs officials and experts. This provided an opportunity of getting reliable data, and a chance for the interviewer and interviewees to have better interaction and clarification of issues. Secondary data gathered from government documents, journals, and published and/or unpublished research papers. The review of literature and hypothesis developed by the researcher was used as a guideline for the development of the questionnaire. Data collected from the MSEs included MSE owners related data: age, sex, education level, business experience, motivation, life of the enterprise, location of the enterprise, size of employee, operation sector, availability of business plan...etc and institutional factors: access to water supply, access to BDS, access to power supply, market linkage, access to finance, support from NGOs, access to transportation and social network.

The questionnaire contained both open-ended and closeended questions. The questionnaire was designed in English language and translated to Amharic language because all respondents cannot clearly understand English language.

\subsection{Methods of Data Analysis}

The data collected from respondents edited, coded and entered into computer software called statistical package for social science. Then, descriptive statistics such as percentage, mean, standard deviations and frequency distributions were used to analyze data obtained through questionnaire regarding factors determining growth of MSE. The econometric analysis tool that is binary logistic regression model was used to identify the determinants of MSE growth. Qualitative data obtained from MSEs officials and experts was analyzed through narration and interpretation qualitatively. To determine the growth status of MSEs, information has to be collected and an appropriate measure of aggregate growth has to be used. As argued by Baum and others [12] growth measure all depends upon the ease of availability of the data and good judgment of the researcher, as a result, from the available alternatives of aggregate growth measures (capital, sales, profit, employment and etc) [13]. This study used employment size and capital as an objective measure of MSEs growth. Accordingly, MSEs growth rate was computed by taking the natural logarithm of change in employment size /capital over the life of the firm following Evans [14]) model. Taking the calculated growth rate, the MSEs are classified into two broad categories i.e., growing (if growth rate $>0$ ) and non growing (if growth rate $\leq 0$ ) following Cheng [15] and represented in the model by 1 for the growing and 0 for survival MSEs.

The binary logistic regression model is selected due to the nature of dependent variable, if the dependent variable is categorical variable with only two categories (growing and non-growing valued as $1 \& 0$ respectively), binary logistic (logit) regression is appropriate.

\section{Model Specification}

In this study MSEs are assumed to be either growing or non-growing. Hence the binary choice logistic regression model that assumes dichotomous dependent variable which takes either 1 or 0 value depending on $\mathrm{Y}^{*}$ is used, this is specified as. 


$$
\mathbf{Y}=\left\{\frac{1 \text { if } \mathrm{Y}^{*}>0}{\mathbf{0} \text { if } \mathrm{Y}^{*} \leq 0}\right.
$$

In a qualitative response model, the probability that $\mathrm{Y}=1$ is given by the sign of the latent variable that is the probability that the latent variable becomes positive.

Table 1 shows the description and measurement of independent variables, and their expected relation with the dependent variable.

Table 1. Definition and units of measurement of explanatory variables used in binary logit model.

\begin{tabular}{|c|c|c|}
\hline Variable & Description and measurement & Sign \\
\hline AGE & $\begin{array}{l}\text { is dummy variable taking value } 1 \text { for the } \\
\text { average age of owners under } 29 \text { and } 0 \text { for } \\
\text { above } 29\end{array}$ & - \\
\hline EDUCATION & $\begin{array}{l}\text { Dummy taking value } 1 \text { if the owners } \\
\text { education level is } \geq 50 \% \text { over } 12^{\text {th }} \text { and } 0 \text { for } \\
\text { under } 12^{\text {th }}\end{array}$ & + \\
\hline EXPERIENCE & $\begin{array}{l}\text { Dummy } 1 \text { if } \geq 50 \% \text { of owners have Previous } \\
\text { business experience of MSEs \& } 0 \text { otherwise }\end{array}$ & + \\
\hline MOTIVATION & $\begin{array}{l}\text { Dummy } 1 \text { if } \geq 50 \% \text { of owners join MSE by } \\
\text { choice \& } 0 \text { if it is by lack of alternative }\end{array}$ & + \\
\hline TRAINING & $\begin{array}{l}\text { Dummy } 1 \text { if } \geq 50 \% \text { of owners had } \\
\text { entrepreneurship training on MSE, } 0 \\
\text { otherwise }\end{array}$ & + \\
\hline LOCATION & $\begin{array}{l}\text { Dummy taking value } 1 \text { if enterprise found } \\
\text { nearest MSEs \& } 0 \text { for located far }\end{array}$ & + \\
\hline STARCAP & Continuous, startup capital of the enterprise & + \\
\hline INTIALEMPLOY & Continuous, Initial employment size & - \\
\hline MEMBER & Continuous, Number of owners & - \\
\hline BUSPLAN & $\begin{array}{l}\text { Dummy } 1 \text { if the business plan available for } \\
\text { enterprise \& } 0 \text { otherwise }\end{array}$ & + \\
\hline SECTOR & $\begin{array}{l}\text { Categorical } 1 \text { if sector is service } \& 0 \text { for } \\
\text { otherwise }\end{array}$ & + \\
\hline ACCFIN & $\begin{array}{l}\text { Dummy } 1 \text { if enterprises have access to } \\
\text { finance \& } 0 \text { otherwise }\end{array}$ & + \\
\hline ACCW & $\begin{array}{l}\text { Dummy taking value } 1 \text { if access to water } \\
\text { supply \& 0otherwise }\end{array}$ & + \\
\hline $\mathrm{ACCP}$ & $\begin{array}{l}\text { Dummy taking value } 1 \text { if they have sufficient } \\
\text { power supply \& } 0 \text { otherwise }\end{array}$ & + \\
\hline ACCT & $\begin{array}{l}\text { Dummy taking value } 1 \text { if they have access to } \\
\text { transportation \& } 0 \text { otherwise }\end{array}$ & + \\
\hline ACCBDS & $\begin{array}{l}\text { Dummy taking value } 1 \text { if they have access to } \\
\text { Business development service (BDS) \& } 0 \\
\text { otherwise }\end{array}$ & + \\
\hline ACCMKTL & $\begin{array}{l}\text { Dummy taking value } 1 \text { if they have access to } \\
\text { market linkage and } 0 \text { otherwise }\end{array}$ & + \\
\hline MATSUPP & $\begin{array}{l}\text { Dummy taking value } 1 \text { if they received } \\
\text { material support from NGOs and } 0 \text { otherwise }\end{array}$ & + \\
\hline SOCNTWK & $\begin{array}{l}\text { Dummy taking value } 1 \text { if involvement in } \\
\text { social network\& } 0 \text { otherwise }\end{array}$ & + \\
\hline
\end{tabular}

\section{Result and Discussion}

\subsection{Descriptive Statistics and Discussion}

As discussed in the methodology part, for the purpose of examining determinants of Micro and Small Enterprises (MSEs) growth, 100 MSEs were taken as sample and questionnaires distributed to representatives of sampled MSEs and all questionnaire were returned.

\subsubsection{Status of MSEs in Terms of Employment Growth and Capital Growth}

From the available alternatives of aggregate growth measures (capital, sales, profit, employment and etc) this study used employment and capital as growth measure of MSEs growth. Accordingly, MSEs growth rate is computed by taking the natural logarithm of change in employment size /capital over the life of the firm following Evans [14] model. Taking the calculated growth rate, the MSEs are classified into two broad categories, i.e. growing (if growth rate $>0$ ) and non growing (if growth rate $\leq 0$ ) following Cheng [15] and represented in the model by 1 for the growing and 0 for survival.

Out of the total sample, $60 \%$ of MSEs are found non growing and only $40 \%$ of them were growing. Figure 1 shows the status of MSEs measured in terms of employment growth rate.

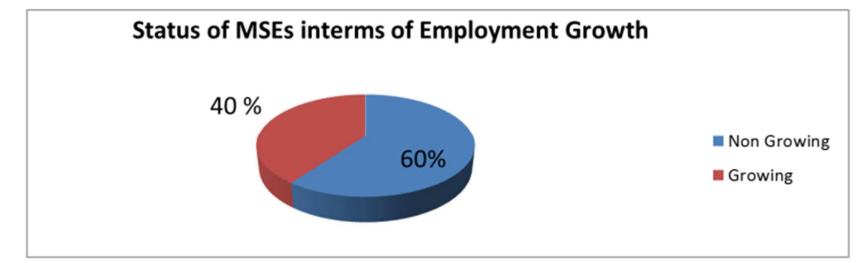

Figure 1. Status of MSEs in terms of Employment Source: survey data, 2016.

This result supports the findings of Gebreeyesus [9] who found $69 \%$ of MSEs are found non growing types. Even though the percentage of non growing MSEs is greater than the findings of Wasihun and Paul [10] who found that $75.6 \%$ of the MSEs are unable to grow at all since start up and only $21.9 \%$ of the MSEs were added workers, the majority of MSEs are non growing.

In terms of capital growth, out of the total sample, $69 \%$ of MSEs found growing and $31 \%$ of MSEs were non growing. Scholars argue that the safe way of measuring growth of firms is to have comprehensive measures of success than relying on a single indicator. This study reveals the scholars argument. Majority of MSEs are non growing in terms of employment but they are growing in terms of capital in the study area (Figure 2).

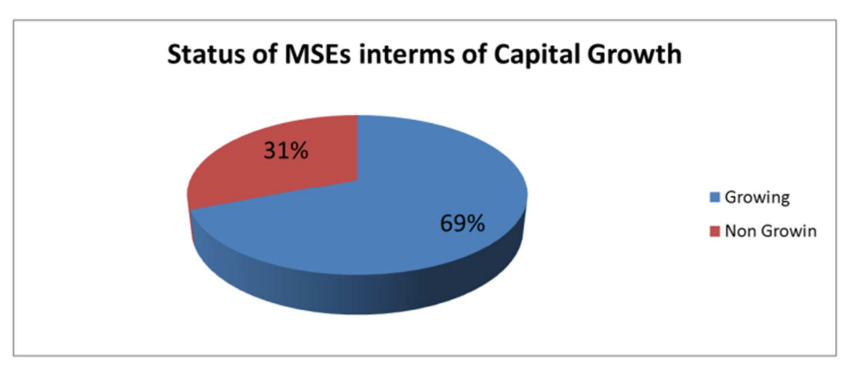

Source: Survey data, 2016

Figure 2. Status of MSEs in terms of capital growth.

The survey result from Table 2 shows that $77 \%$ of sample MSEs are group owned, $17 \%$ are family owned and only $6 \%$ of MSEs are private owned. This imply that majority of MSEs in the study area are group owned, about $43 \%$ of 
MSEs operate in rental house, $37 \%$ in government constructed, $19 \%$ at home and $1 \%$ at NGO constructed. About $59 \%$ of MSEs responded that the place they are working is enough for their business and the rest $41 \%$ responded that they have no enough space for working.

Table 2. Type of enterprise and working place.

\begin{tabular}{llll}
\hline Variable & Category & Frequency & Percent \\
\hline \multirow{5}{*}{ Enterprise type } & Group & 77 & 77.0 \\
& Private & 6 & 6.0 \\
& Family & 17 & 17.0 \\
& Total & 100 & 100.0 \\
& Rental & 43 & 43.0 \\
& Home & 19 & 19.0 \\
Working place & government constructed & 37 & 37.0 \\
& NGO constructed & 1 & 1.0 \\
& Total & 100 & 100.0 \\
\hline
\end{tabular}

Source: Survey data, 2016

\subsubsection{Owner Related Factors and Employment Growth}

i. Average age of MSE owners and Education Level

Out of the total sample, $36 \%$ of MSE owner's average age is above 29 years old and the majority $64 \%$ of MSE owner's average age is under 29 years old i.e. most of MSE owners are young people. Among the growing MSEs, majority (80\%) were young MSE owners and only $20 \%$ were above 29 years old. In contrary, among the non growing MSEs 47 percent of MSE owner's average age is above 29 years old and 53 percent were under 29. As Table 3 shows, average growth rate for younger MSE owners is greater than average growth rate of MSE owners above 29 years old. It is found that there is statistically significant mean difference between growing and non growing MSEs at 1\% significance level. This is consistent with the study of Amran [16] which shows that a negative relationship between owner's age and business performance suggesting that matured owners underperform, while the young owners are more aggressive in enhancing the firm value. It also supports the finding of Garoma [17] who found that most successful entrepreneurs are found within 20-25 years of age on average.

Most previous studies show that formal education has a positive impact on the effectiveness of MSEs. In this study out of the total sample, $56 \%$ of MSEs have owners who are under grade 12 and $44 \%$ of MSEs have owners that completed 12 and above. Out of the growing MSEs 70\% of MSE Owners are completed 12 grade and above 12 grade. Only $30 \%$ of growing MSEs have owners with education level under 12 grade. This shows that, most of growing MSE's owners has high education level. But there is slight difference between the average growth rate of MSEs with high education level and low education level. According Table 3 the average growth rate of MSEs with owners under grade 12 is greater than average growth rate of MSEs with owners above 12 grade which is $18.8 \%$ and $16.8 \%$ respectively. The chi-square test showed that there is significant mean difference between growing and non growing MSEs at less than 1\% significance level.

Table 3. Age of owner and education level.

\begin{tabular}{|c|c|c|c|c|c|c|c|c|}
\hline \multirow{3}{*}{ Variable } & \multirow{3}{*}{ Category } & \multicolumn{6}{|c|}{ Employment Growth Status of MSE } & \multirow{3}{*}{ Average growth rate } \\
\hline & & \multicolumn{2}{|c|}{ Growing MSEs } & \multicolumn{2}{|c|}{ Non-Growing MSEs } & \multicolumn{2}{|c|}{ Total } & \\
\hline & & $\mathbf{N}$ & $\%$ & $\mathbf{N}$ & $\%$ & $\mathbf{N}$ & $\%$ & \\
\hline \multirow{4}{*}{ Age } & Above 29 yrs & 8 & 20 & 28 & 47 & 36 & 36 & 0.135 \\
\hline & Under 29 yrs & 32 & 80 & 32 & 53 & 64 & 64 & 0.184 \\
\hline & Total & 40 & 100 & 60 & 100 & 100 & 100 & 0.174 \\
\hline & Chi-square & & & & & 18.2 & & \\
\hline \multirow{4}{*}{ Education Level } & 12 and above & 28 & 70 & 16 & 27 & 44 & 44 & 0.168 \\
\hline & Under 12 & 12 & 30 & 44 & 73 & 56 & 56 & 0.188 \\
\hline & Total & 40 & 100 & 60 & 100 & 100 & 100 & 0.174 \\
\hline & Chi-square & & & & & $7.4 *$ & & \\
\hline
\end{tabular}

Source: Survey data, 2016. *** indicates significant at $1 \%$

ii. Entrepreneurship Training, Previous experience and Employment Growth

As Table 4indicated, about $65 \%$ of MSEs owners participated in entrepreneurship training and $35 \%$ of them were not participated in the training. Out of the growing MSEs, $77 \%$ of owners participated in training and only $23 \%$ owners were not participated. Among the non growing MSEs $65 \%$ were trained and $35 \%$ were not trained. Chi-square test of entrepreneurship training between the two groups was run and the difference was found to be statistically significant at $5 \%$ level of significance. This result is inconsistent with the findings of Garoma [17] who found insignificant association between Entrepreneurial training of the owner and success on micro enterprises in Addis Ababa.
Many studies found that owner-managers employment experience prior to the start up tend to link with SMEs success. According to the survey result, about $62 \%$ of MSEs owners had previous business experience and the rest $38 \mathrm{had}$ no previous experience. Among the growing MSEs, $78 \%$ of MSEs owners have previous business experience and only $22 \%$ had no experience. Out of the total non growing MSEs, $48 \%$ had no experience and $52 \%$ had business experience. Table 4 shows that average growth rate of MSEs which have previous experience is greater than average growth rate of MSEs which have no business experience. Entrepreneurship training was found statistically significant at $1 \%$ significance level. This is consistent with the findings of Garoma [17] and Tassew and others [18]. 
Table 4. Entrepreneurship training, experience and employment growth.

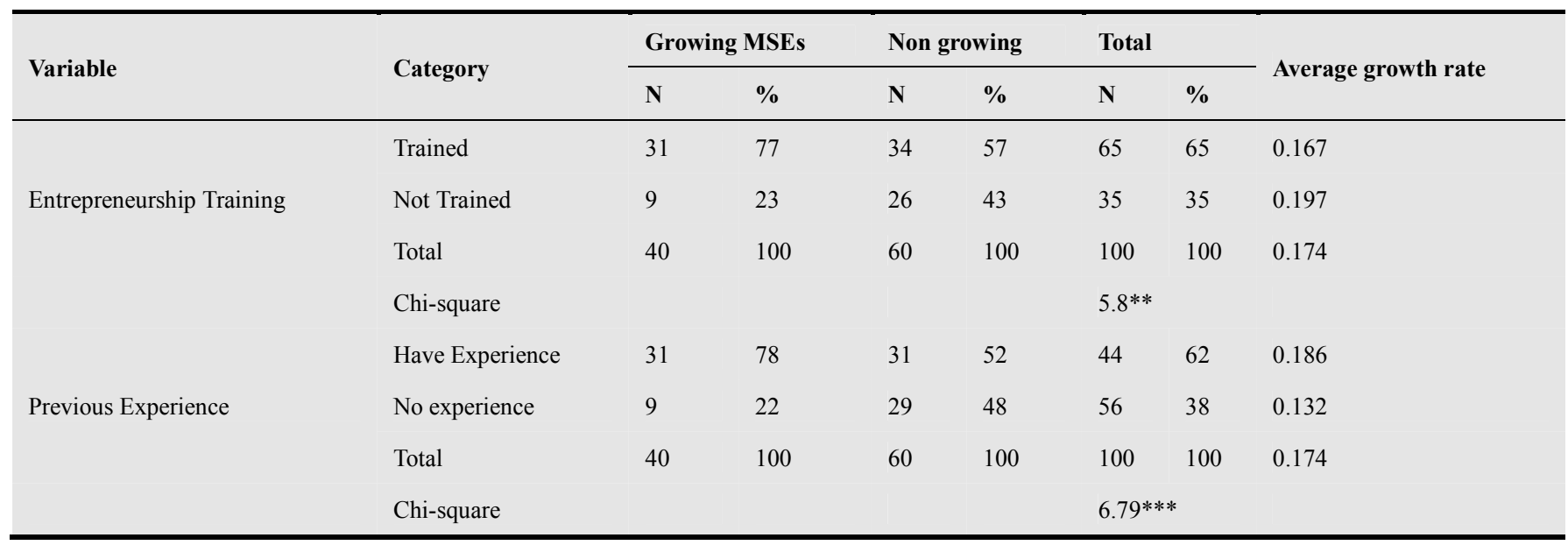

Source: SPSS result from survey data (2016). *** and ** indicate significant at $1 \% \& 5 \%$

iii. Motivation of MSE owners and Employment Growth

The survey result in Table 5 indicated that about $55 \%$ of MSE owners joined MSE because of lack of alternative, while $45 \%$ of them joined by their choice. Among the growing MSEs $75 \%$ of MSEsowners joined MSE by choice, $25 \%$ joined because of lack of alternative. Out of the total non growing MSEs 75\% of MSE's owners joined MSE because of lack of alternative, $25 \%$ by choice. Chi-square test result showed that there significant $(\mathrm{p}<0.01)$ difference between the growing and non growing MSEs regarding to motivation. The result of this survey is inconsistent with Block and Sandner [19] they found that being an entrepreneur out of necessity or opportunity driven motives does not have significant impact on duration in selfemployment. But it is consistent with Garoma [17].

Table 5. Motivation of owner and employment growth.

\begin{tabular}{lllllllll}
\hline \multirow{2}{*}{ Variable } & Type & \multicolumn{2}{c}{ Growing MSEs } & \multicolumn{2}{c}{ Non growing MSEs } & \multicolumn{2}{c}{ Total } & Average growth rate \\
\cline { 2 - 7 } & & $\mathbf{N}$ & $\mathbf{\%}$ & $\mathbf{N}$ & $\mathbf{\%}$ & $\mathbf{N}$ & \% \\
\hline \multirow{3}{*}{ Motivation } & By choice & 30 & 75 & 15 & 25 & 45 & 45 & 0.166 \\
& Lack of alternative & 10 & 25 & 45 & 75 & 55 & 55 & 0.200 \\
& Total & 40 & 100 & 60 & 100 & 60 & 100 & 0.174 \\
& Chi-square & & & & & $24.24 * * *$ & \\
\hline
\end{tabular}

Source: Survey data, 2016. ${ }^{* * *}$ indicates significant at $1 \%$

\subsubsection{Business Related Factors and Employment Growth}

i. Location of enterprise and availability of business plan

Out of the total sample, about $69 \%$ of MSEs operate their business near to the main road or busy street and $31 \%$ of them located far from the main road or busy street. Among the growing MSEs, $87 \%$ of MSEs are located near to the main road and only $13 \%$ located far from the main road. Out of the total non growing MSEs, 57\% MSEs located near to the main road. The average growth rate for MSEs located far from main road is greater than those who operate near to main road. Chi-square test for location of enterprise showed that there is significant association between growth of MSEs and location of enterprise at $1 \%$ significance level. The findings of Habtamu is consistent with this survey finding who found that MSEs operate in main road side have low probability of growth compared to those operate out of the town .The result is contrary to the findings of Eshetu \&
Mammo [20]; Gebreyesus [9], they found that MSEs located at main road side exhibit higher growth compared to MSEs located out of town.

As Table 6 indicates $73 \%$ of MSEs had plan for their business out of the total sample and $27 \%$ had no business plan. Almost all growing MSEs (90\%) had business plan and only $10 \%$ of growing MSEs had no business plan. About $62 \%$ of non growing MSEs had business plan and the remaining 38\% had no business plan. Growing MSEs which had business plan have higher average growth rate compared to MSEs which have no business plan. Average growth rate for MSEs with business plan is 17.6 and 14.8 for those which had no plan. This is consistent with the finding of Siropolis [21] who found that Business that do not prepare a business plans have a greater chance of failure than business that do. It was found that there is significance difference between growing and non growing MSEs at 5\% significance level. 
Table 6. Location of enterprise, Availability of Business plan and employment growth.

\begin{tabular}{|c|c|c|c|c|c|c|c|c|}
\hline \multirow{2}{*}{ Variable } & \multirow{2}{*}{ Type } & \multicolumn{2}{|c|}{ Growing MSEs } & \multicolumn{2}{|c|}{ Non growing MSEs } & \multicolumn{2}{|c|}{ Total } & \multirow{2}{*}{ Average growth } \\
\hline & & $\mathbf{N}$ & $\%$ & $\mathbf{N}$ & $\%$ & $\mathbf{N}$ & $\%$ & \\
\hline \multirow[t]{4}{*}{ Location } & Near to main road or busy street & 35 & 87 & 34 & 57 & 69 & 69 & 0.16 \\
\hline & Far from main road & 5 & 13 & 26 & 43 & 31 & 31 & 0.25 \\
\hline & Total & 40 & 100 & 60 & 100 & 100 & 100 & 0.17 \\
\hline & Chi square & & & \multicolumn{5}{|c|}{$10.66^{* * *}$} \\
\hline \multirow[t]{4}{*}{ Business plan } & Have Business plan & 36 & 90 & 37 & 62 & 73 & 73 & 0.17 \\
\hline & No Business plan & 4 & 10 & 23 & 38 & 27 & 27 & 0.15 \\
\hline & Total & 40 & 100 & 60 & 100 & 100 & 100 & 0.17 \\
\hline & Chi square & & & \multicolumn{5}{|c|}{$9.7^{* *}$} \\
\hline
\end{tabular}

Source: Survey data, 2016.*** and ** indicate significant at $1 \%$ \& 5\%

ii. Sector MSEs operate

Out of 26 MSEs operate in service sector only 8 MSEs (30\%) are growing and the rest 18 MSEs (70\%) are non growing. Among 12 MSEs operate in manufacturing sector 50\% are growing and 50\% are non growing. Out of 34 MSEs in construction sector 23 MSEs (68\%) are growing and only 11 MSEs are non growing. Only $2(10 \%)$ MSEs in trade sector are growing, the rest 17 (90\%) are non growing. Among 9 MSEs operate in urban agriculture only 1 MSE is growing type, the rest $90 \%$ of MSEs are non growing. Out of the total growing MSEs, service sector accounts $20 \%$, manufacturing $15 \%$, construction $58 \%$, trade $5 \%$ and urban agriculture $2 \%$ (Table 7 ).

Table 7. Sector MSEs operate and Employment growth.

\begin{tabular}{lllllllll}
\hline \multirow{2}{*}{ Variable } & Type & \multicolumn{2}{c}{ Growing MSEs } & \multicolumn{2}{l}{ Non growing MSEs } & Total & Average growth rate \\
\cline { 3 - 7 } & N & $\mathbf{N}$ & $\mathbf{N}$ & $\mathbf{\%}$ & $\mathbf{N}$ & $\mathbf{\%}$ & \\
\hline \multirow{5}{*}{ Sector } & Service & 8 & 20 & 18 & 30 & 26 & 26 & .156 \\
& Manufacturing & 6 & 15 & 6 & 10 & 12 & 12 & .147 \\
& Construction & 23 & 58 & 11 & 19 & 34 & 34 & .180 \\
& Trade & 2 & 5 & 17 & 28 & 19 & 19 & .084 \\
& Urban Agriculture & 1 & 2 & 8 & 13 & 9 & 9 & .510 \\
& Total & 40 & 100 & 60 & 100 & 100 & 100 & .174 \\
& Chi square & & & & & & $22.25 * * *$ & \\
\hline
\end{tabular}

Source: Survey data, 2016. *** indicates significant at $1 \%$

iii. Startup capital of MSEs and employment growth

The average startup capital of all MSEs found to be 25870 with the standard deviation equal to 38588 . The minimum and maximum startup capital is 1000 birr and 250000 birr respectively. This implies that there is a big difference on startup capital among MSEs. When we see growing and non growing MSEs in terms of employment separately, average startup capital for growing MSEs is 43266 and 33614 for non growing MSEs. Minimum and maximum startup capital for growing MSEs is 2000 and 200000 respectively and it is 1000 and 250000 for non growing MSEs. Standard deviation indicates that variation of startup capital on growing MSEs is higher than those non growing MSEs (Table 8). The mean differences for startup capital of MSEs were found to be significant at less than $1 \%$ significance level.

Table 8. Startup Capital of MSEs and Employment Growth.

\begin{tabular}{llll}
\hline Variable & Growing MSE(birr) & Non growing(birr) & Total(birr) \\
\hline Startup capital & & & \\
Mean & 36650 & 18683 & 25870 \\
SD & 43266 & 33614 & 38588 \\
Minimum & 2000 & 1000 & 1000 \\
Maximum & 200000 & 250000 & 250000 \\
t-test value & & & $6.704 * * *$ \\
\hline
\end{tabular}

Source:Survey data, 2016.*** indicates significant at $1 \%$

iv.Initial employment size and Number of owners

Initial employment size in this study ranges from 1-27.The average initial employment size is 5.The standard deviation indicates that variation for non growing MSEs is higher than growing MSEs; it is 4.464 and 2.300 respectively. Minimum initial employment for growing MSEs is 1 and the maximum is 13.Average initial employment size with 4.88 for growing
MSEs and 5.20 for non growing MSEs. The mean differences for initial employment size were found to be significant at $1 \%$ probability level.

Accounted about $77 \%$ of MSEs are group owned, $17 \%$ family owned and $6 \%$ are privately owned. Number of owners in this study refers number of enterprise members either group owned or family owned. There is slight 
difference on number of owners and initial employment size. Since most MSEs start business by owners only. They add worker through time. Minimum and maximum number of MSE owners range from 1-25. Average number of owner is 5.15. Variation for non growing MSEs is higher than growing
MSEs, it is 4.337 and 2.407 respectively (Table 9). Minimum number of owner for non growing MSEs is 1 and the maximum is 25.T- test showed that the number of owners was found to be significance at $1 \%$ probability level.

Table 9. Initial employment, number of owners and employment growth.

\begin{tabular}{|c|c|c|c|}
\hline Variable & Growing MSE(birr) & Non growing(birr) & Total \\
\hline \multicolumn{4}{|c|}{ Initial employment } \\
\hline Mean & 4.9 & 5.20 & 5 \\
\hline SD & 2.3 & 4.46 & 3.7 \\
\hline Minimum & 1 & 1 & 1 \\
\hline Maximum & 13 & 27 & 27 \\
\hline t-test value & & & $13.5 * * *$ \\
\hline \multicolumn{4}{|c|}{ Number of owners } \\
\hline $\mathrm{SD}$ & 2.4 & 4.4 & 3.7 \\
\hline Minimum & 1 & 1 & 1 \\
\hline Maximum & 13 & 25 & 25 \\
\hline t-test value & & & $13.536 * * *$ \\
\hline
\end{tabular}

Source: Survey data, 2016.*** indicates significant at $1 \%$

v. Employment growth and institutional factors

Table 10 shows out of the total sample, $55 \%$ of MSEs have access to business development service (BDS) and the rest $47 \%$ have no access. Out of growing MSEs, $83 \%$ of MSEs had access to BDS and among non growing MSEs $73 \%$ majority of MSEs had no access to BDS. Average growth rate for MSEs which had access to BDS is higher than those who have no access which is $18 \%$ for those which had access and $13 \%$ for MSEs have no access. Chi-square test showed that the difference in relation to access to business development service was found to be significance at $1 \%$ significance level.

Table 10. Institutional factors and Employment growth.

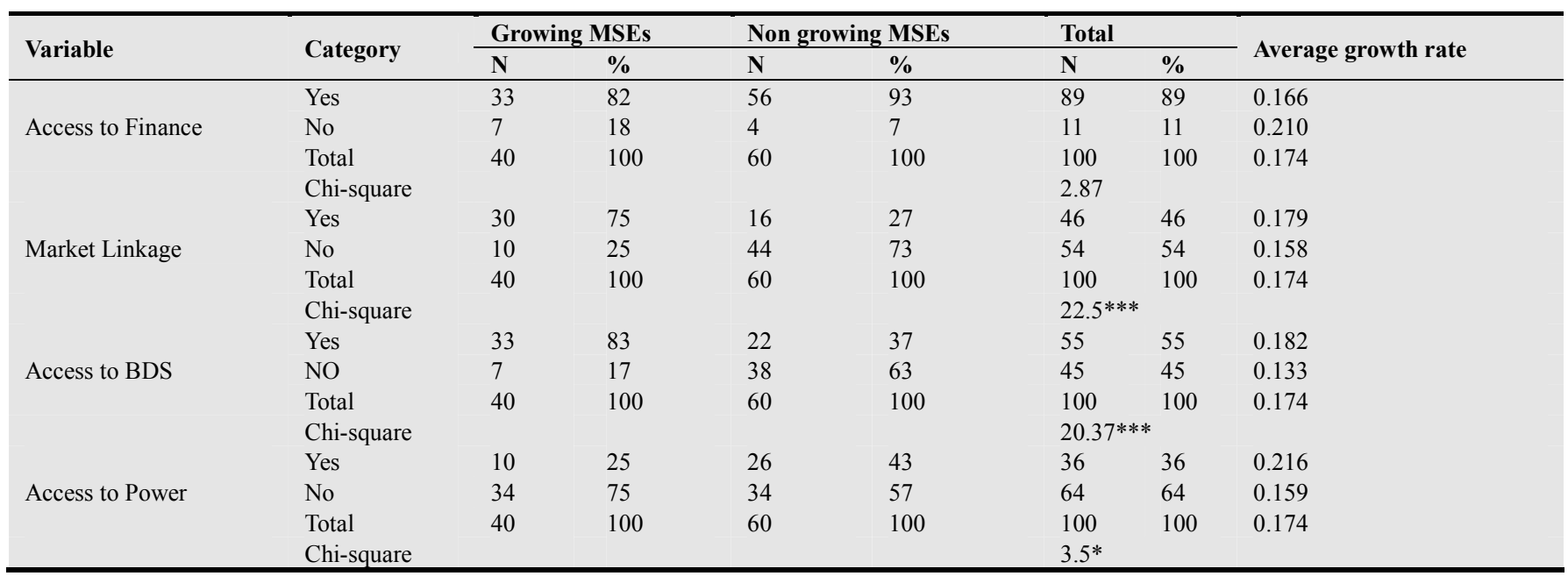

Source: SPSS result from survey data (2016). $* * * \& *$ indicate significant at $1 \%$ and $10 \%$

Out of the total samples, market linkage was created for $46 \%$ MSEs. Above $90 \%$ of market linkage is facilitated by government. Among the total growing MSEs, $75 \%$ of MSEs had access to market linkage. Among non growing MSEs, $73 \%$ of MSEs had no access to market linkage. Average growth rate for MSEs which had access to market linkage is $17.9 \%$, while it is $15.8 \%$ for those who had no market linkage. Chi-square test run showed that the difference in relation to access to market linkage was found to be significance at $1 \%$ probability level.

Almost all (98\%) MSEs involved in social network and only 2 MSEs responded that they had no social network.
Almost $90 \%$ of MSEs responded that they had strong network with their customers and the remaining $10 \%$ have strong relation with neighbors and Ikub members. The chisquare test showed that there is insignificant relation with social network and employment growth of MSEs.

Only $36 \%$ of MSEs have access to sufficient power supply. The majority of MSEs (64\%) have no access to sufficient power supply. Almost all of MSEs (92\%) had access to transport and only $8 \%$ of MSEs responded that they have no access to transport. It was found that there is significant relation between growth of MSEs and power supply at $1 \%$ significance level. 


\subsection{Descriptive Statistics for Capital Growth of MSEs}

\subsubsection{Capital Growth and Owner Related Factors}

Among growing MSEs, $60 \%$ of MSEs had owner with education level 12 complete and above, while $40 \%$ had owners under grade 12 .About $90 \%$ of non growing MSEs had owners which are under grade 12, while only $10 \%$ MSEs are non growing with MSE owners 12 completed and above. As the Table 11 shows that the average growth rate for MSEs with 12 completed and above is not better than those MESs with under grade 12.There is significant relation respect to education level of owners with $1 \%$ significance level.

There is slight difference on average capital growth rate of MSEs regarding to owners with previous experience and without experience. Out of the total growing MSEs, about $70 \%$ of owners had previous experience and only $30 \%$ of growing MSEs had no previous experience. Out of non growing MSEs, $55 \%$ of MSEs owners' had no previous experience. Average capital growth rate for MSEs with owners with previous experience is $36 \%$ and the remaining $35 \%$ had no experience. Previous experience showed a significant difference $(\mathrm{P}<0.01)$ between growing and non growing.

Out of the total non growing MSEs, $90 \%$ of MSE owners joined micro and small enterprise because of lack of alternative i.e. they are not interested to join MSEs voluntarily. About $61 \%$ of growing MSE's owners joined micro and small enterprise by choice. There is visible difference on average growth rate. Average growth rate of MSEs which had owners joined MSE by choice is $39 \%$ while it is $27 \%$ for those MSEs which joined because of lack of alternative. It was found that motivation had significant relation with capital growth of MSEs at $1 \%$ significance level (Table 11).

Table 11. Capital growth and owner related factors.

\begin{tabular}{|c|c|c|c|c|c|c|c|c|}
\hline \multirow[t]{2}{*}{ Variable } & \multirow[t]{2}{*}{ Type } & \multicolumn{2}{|c|}{ Growing MSEs } & \multicolumn{2}{|c|}{ Non growing } & \multicolumn{2}{|c|}{ Total } & \multirow[t]{2}{*}{ Average growth rate } \\
\hline & & $\mathrm{N}$ & $\%$ & $\mathrm{~N}$ & $\%$ & $\mathrm{~N}$ & $\%$ & \\
\hline \multirow[t]{4}{*}{ Age of owner } & Above 29 yrs & 22 & 32 & 14 & 45 & 36 & 36 & 0.34 \\
\hline & Under 29 yrs & 47 & 68 & 17 & 55 & 64 & 64 & 0.37 \\
\hline & Total & 69 & 100 & 31 & 100 & 100 & 100 & 0.36 \\
\hline & Chi Square & & & & & 1.63 & & \\
\hline \multirow{2}{*}{$\begin{array}{l}\text { Education } \\
\text { Level }\end{array}$} & 12 and above & 41 & 60 & 3 & 10 & 44 & 44 & 0.34 \\
\hline & Under 12 & 28 & 40 & 28 & 90 & 56 & 56 & 0.39 \\
\hline \multirow{5}{*}{ Entrepreneurship training } & Chi Square & & & & & 21.48 & & \\
\hline & Trained & 48 & 70 & 17 & 55 & 65 & 65 & 0.35 \\
\hline & Not Trained & 21 & 30 & 14 & 45 & 35 & 55 & 0.37 \\
\hline & Total & 69 & 100 & 31 & 100 & 100 & 100 & 0.36 \\
\hline & Chi Square & & & & & 2.49 & & \\
\hline \multirow[b]{2}{*}{ Previous experience } & Have Experience & 48 & 70 & 14 & 45 & 62 & 62 & 0.36 \\
\hline & No experience & 21 & 30 & 17 & 55 & 38 & 38 & 0.35 \\
\hline \multirow{5}{*}{ Motivation } & Chi Square & & & & & $5.40^{\circ}$ & & \\
\hline & By choice & 43 & 62 & 2 & 7 & 45 & 45 & 0.39 \\
\hline & Lack of alternative & 26 & 38 & 29 & 93 & 55 & 55 & 0.27 \\
\hline & Total & 69 & 100 & 31 & 100 & 100 & 100 & 0.36 \\
\hline & Chi Square & & & & & $26.9^{7}$ & & \\
\hline
\end{tabular}

Source: Survey data (2016).*** \&* indicate significant at $1 \%$ and $10 \%$

\subsubsection{Capital Growth and Business Related Factors}

Table 12 shows that the average startup capital of MSEs found to be 25870 with 38588 the standard deviation. The minimum and maximum startup capital is 1000 birr and 250000 birr respectively. When we see growing and non growing MSEs separately, average startup capital for growing MSEs was 24246.38 and 29483.87 for non growing
MSEs. This implies that there is a big difference on startup capital of MSEs. Minimum and maximum startup capital for growing MSEs is 1000 and 200000 respectively. T-test of startup capital showed that there is significant association between capital growth and startup capital at $1 \%$ significance level.

Table 12. Startup capital and capital growth.

\begin{tabular}{llll}
\hline Variable & Growing MSE & Non growing & Total \\
\hline Startup capital & & & 29483 \\
Mean & 24246 & 50155 & 38588 \\
SD & 32396 & 5000 & 1000 \\
Minimum & 1000 & 250000 & 250000 \\
Maximum & 200000 & & $6.704 * * *$ \\
T-test value & & & \\
\hline
\end{tabular}

Source: SPSS result from survey data (2016). *** indicates significant at $1 \%$ 
Business related factors discussed in this study are location of enterprise, availability of business plan, sector MSEs operate and startup capital of MSEs. Out of 69 growing MSEs, $77 \%$ operate their business near to the main road or on busy streets, while $23 \%$ of MSEs located far from main road. Out of 31 non growing MSEs, 52\% operate their business near to the main road or on busy streets and $48 \%$ located far from main road. Average capital growth rate for MSEs operate near the main road is greater than those operate out of the main road; it is $39 \%$ and $27 \%$ respectively. Chi-square test of business plan showed that there is significant relation with capital growth and location of enterprise at 5\% significance level (Table 13).

Out of the total growing MSEs, $36 \%$ is from construction and the remaining $26 \%, 19 \%, 13 \%, 6 \%$ are from service, trade, manufacturing and urban agriculture respectively. Average growth rate for MSEs operate in manufacturing is higher than MSEs operate on other sectors. MSEs operate in trade sector had least average growth rate compared with other sectors. Out of the total growing MSEs, 48\% majority are MSEs start business between 10001-50000 birr, 27\% 5001-10000, 21\% 500-1000, 4\% >100000. MSEs start business with startup capital at the range of 5001-10000 registered higher average growth than other MSEs. T-test of startup capital showed that there is significant relation between capital growth and startup capital at less than $1 \%$ significance level.

Table 13. Capital growth and Business related factors.

\begin{tabular}{|c|c|c|c|c|c|c|c|c|}
\hline \multirow{2}{*}{ Variable } & \multirow{2}{*}{ Category } & \multicolumn{2}{|c|}{ Growing MSEs } & \multicolumn{2}{|c|}{ Non growing } & \multicolumn{2}{|c|}{ Total } & \multirow[t]{2}{*}{ Mean for growing } \\
\hline & & $\mathbf{N}$ & $\%$ & $\mathbf{N}$ & $\%$ & $\mathbf{N}$ & $\%$ & \\
\hline \multirow{4}{*}{ Location of enterprise } & Near to main road & 53 & 77 & 16 & 52 & 69 & 69 & 0.39 \\
\hline & Far from main road & 16 & 23 & 15 & 48 & 31 & 31 & 0.24 \\
\hline & Total & 69 & 100 & 31 & 100 & 100 & 100 & 0.36 \\
\hline & Chi square & & & & & 6.350 & & \\
\hline \multirow{4}{*}{ Business plan } & Have Business plan & 52 & 75 & 21 & 68 & 73 & 73 & 0.39 \\
\hline & No Business plan & 17 & 25 & 10 & 32 & 27 & 27 & 0.26 \\
\hline & Total & 69 & 100 & 31 & 100 & 100 & 100 & 0.36 \\
\hline & Chi square & & & & & 0.630 & & \\
\hline \multirow{7}{*}{ Sector } & Service & 18 & 26 & 8 & 26 & 26 & 26 & 0.27 \\
\hline & Manufacturing & 9 & 13 & 3 & 10 & 12 & 12 & 0.54 \\
\hline & Construction & 25 & 36 & 9 & 29 & 34 & 34 & 0.44 \\
\hline & Trade & 13 & 19 & 6 & 19 & 19 & 19 & .22 \\
\hline & Urban Agriculture & 4 & 6 & 5 & 16 & 9 & 9 & 0.31 \\
\hline & Total & 69 & 100 & 31 & 100 & 100 & 100 & 0.36 \\
\hline & Chi square & & & & & 3.069 & & \\
\hline \multirow{7}{*}{ Capital Category } & $100-5000$ & 14 & 21 & 3 & 10 & 17 & 17.2 & 0.27 \\
\hline & $5001-10000$ & 18 & 27 & 9 & 29 & 27 & 27.3 & 0.54 \\
\hline & $10001-50000$ & 33 & 48 & 13 & 51 & 49 & 49.5 & 0.44 \\
\hline & $50001-100000$ & 0 & 0 & 1 & 3 & 1 & 1 & 0.22 \\
\hline & $>100000$ & 3 & 4 & 2 & 7 & 5 & 5.1 & 0.31 \\
\hline & Total & 68 & 100 & 31 & 99 & 99 & 100 & 0.36 \\
\hline & $\mathrm{t}$ - test value & & & & & 25.59 & & \\
\hline
\end{tabular}

Source: Survey data, 2016. *** and ** indicate significant at $1 \%$ \& 5\%

\subsubsection{Initial Employment and Number of Owners}

Initial employment size in this study ranges from 1-27. The average initial employment size is 5.The standard deviation indicates that variation for non growing MSEs is higher than growing MSEs. It is 4.2 and 3.5 respectively. Minimum initial employment for growing MSEs is 1 and the maximum is 27. Average initial employment size is 4.93 for growing MSEs and 5.39 for non growing MSEs. The difference was statistically tested and it was found to be significant at less than $1 \%$ level (Table 14).

As discussed earlier in employment growth section, 77\% of MSEs are group owned, $17 \%$ family owned and $6 \%$ are privately owned. Number of owners in this study refers number of enterprise members either group owned or family owned. There is slight difference on number of owners and initial employment size. Since most MSEs start business by owners only. They add worker through time. Number of MSE owners range from 1-25. Average owner is 5.39. Standard deviation for non growing MSEs is higher than growing MSEs. It is 5.26 and 3.405 respectively. Minimum number of owner for both growing and non growing MSEs is 1 and the maximum is 25 . The difference was statistically tested and it was found to be significant at less than $1 \%$ level. 
Table 14. Initial employment, Number of owners and capital growth.

\begin{tabular}{llll}
\hline Variable & Growing MSE & Non growing & Total \\
\hline Initial employment & & & \\
Mean & 4.93 & 5.39 & 5.07 \\
SD & 3.537 & 4.201 & 3.740 \\
Minimum & 1 & 1 & 1 \\
Maximum & 27 & 25 & 27 \\
t-test value & & & $13.557^{* * *}$ \\
Number of owners & & & \\
Mean & 4.86 & 5.26 & 4.98 \\
SD & 3.405 & 4.274 & 3.679 \\
Minimum & 1 & 1 & 1 \\
Maximum & 25 & 25 & 25 \\
t-test value & & & $13.536^{* * *}$ \\
\hline
\end{tabular}

Source: Survey data, 2016. *** indicates significant at $1 \%$

\subsubsection{Capital Growth and Institutional Factors}

The result found in this study shows that MSEs which had access to finance did not registered better average growth rate compared to those MSEs which had no access. The chi square test showed that there is significant difference at $10 \%$ significance level.

MSEs which had access to market linkage registered higher growth rate than those which had no access to market linkage (Table 15). Among non growing MSEs, 68\% of MSEs had no access to market linkage. Out of growing MSEs, $52 \%$ had access to market linkage, while the rest $48 \%$ had no access. The difference was statistically tested and it was found to be significant at $10 \%$ of significance level. Out of the total non growing MSEs, $81 \%$ of MSEs had no access to BDS, while only $19 \%$ had access to BDS. Out of total growing MSEs, $71 \%$ of MSEs had access to BDS and $29 \%$ had no access. The study result shows that there was difference on average growth rate between MSEs which had access to BDS and which had no access. The chi square test showed that there is significance relation between capital growth and access to business development service at less than $1 \%$ significance level $(\mathrm{p}<0.01)$.

Table 15. Institutional factors and Capital Growth.

\begin{tabular}{|c|c|c|c|c|c|c|c|c|}
\hline \multirow[t]{2}{*}{ Variable } & \multirow[t]{2}{*}{ Category } & \multicolumn{2}{|c|}{ Growing MSE } & \multicolumn{2}{|c|}{ Non growing } & \multicolumn{2}{|l|}{ Total } & \multirow[t]{2}{*}{ Average growth rate } \\
\hline & & $\mathbf{N}$ & $\%$ & $\mathbf{N}$ & $\%$ & $\mathbf{N}$ & $\%$ & \\
\hline \multirow[t]{3}{*}{ Access to Finance } & Yes & 59 & 85 & 30 & 97 & 89 & 89 & 0.39 \\
\hline & No & 10 & 15 & 1 & 3 & 11 & 11 & 0.59 \\
\hline & $\begin{array}{l}\text { Total } \\
\text { Chi-square }\end{array}$ & 69 & 100 & 31 & 100 & $\begin{array}{l}100 \\
2.77 * *\end{array}$ & 100 & 0.36 \\
\hline \multirow[t]{4}{*}{ Market Linkage } & Yes & 36 & 52 & 10 & 32 & 46 & 46 & 0.41 \\
\hline & No & 33 & 48 & 21 & 68 & 54 & 54 & 0.30 \\
\hline & Total & 69 & 100 & 31 & 100 & 100 & 100 & 0.36 \\
\hline & Chi-square & & & & & $3.41 * *$ & & \\
\hline \multirow[t]{4}{*}{ Access to BDS } & Yes & 49 & 71 & 6 & 19 & 55 & 55 & 0.35 \\
\hline & NO & 20 & 29 & 25 & 81 & 45 & 45 & 0.37 \\
\hline & Total & 69 & 100 & 31 & 100 & 100 & 100 & 0.36 \\
\hline & Chi-square & & & & & $23.06 * * *$ & & \\
\hline
\end{tabular}

Source: Survey data, 2016. *** and ** indicate significant at $1 \% \& 5 \%$

\subsection{Econometric Model Result on Determinants of MSES Growth}

Beside descriptive statistical analysis, binary logistic regression model was used to identify determinants of MSEs growth. This study was used employment size and capital to measure the growth of MSES. Accordingly, MSEs growth rate was computed by taking the natural logarithm of change in employment size or capital over the life of the firm [i. e., $\left.M G R=\left(\frac{\ln S_{t^{\prime}}-\ln S_{t}}{E a}\right)\right]$ following Evans [14] model. Where Ea is age of enterprise, $\ln \mathrm{S}_{\mathrm{t}}$, is natural logarithm of current employment size, $\operatorname{lnS}_{\mathrm{t}}$ is natural logarithm of initial employment size. Taking the calculated growth rate, the MSEs are classified in to two broad categories i.e., growing (if growth rate $>0$ ) and non growing (if growth rate $\leq 0$ ) following Cheng [15] and represented in the model by 1 for the growing and 0 for non growing MSEs .

Empirical results of regression analysis were presented separately for each indicator of growth chosen for this study (employment and capital). 19 explanatory variables were used to estimate the binary logistic regression model to identify determinants of MSEs growth. Before discussing about the results of the model, testing the appropriateness of the model is very important. The various goodness of fit measures state that the model fits that data well .The conventional measure of goodness of fit, $\mathrm{R}^{2}$, is not particularly meaningful in binary regression models. Measures similar to $\mathrm{R}^{2}$, called pseudo $\mathrm{R}^{2}$ are available, and there are a variety of them [22]. Generally speaking, the higher the pseudo R-squared statistic, the better the model fits our data.

\subsubsection{Determinants of MSEs Capital Growth}

Among 19 explanatory variables 7 variables were found to be significant in determining probability of MSEs capital growth at less than $10 \%$ of significance level (Table 16). These variables include Education level of MSE owners (EDUOWN), motivation of MSE owner (MOTOWN), and access to finance (ACCF), access to business development service (ACCBDS), number of MSE members/owners (members), initial employment size (INTIALEMPOLY) and social network (SOCIALNTWK).

\subsubsection{Determinants of MSEs Employment Growth}

The result of binary logit regression of employment growth shows that among 19 explanatory variables 6 variables were found significant in determining probability of 
MSEs employment growth with less than $10 \%$ of significance level. These variable include entrepreneurship training (ENTPTRAN), motivation of MSE owner
(MOTOWN), Location of enterprise (LOCENT), access to finance (ACCF), Market linkage (MKTLINKAGE), Access to water (ACCW) (Table 17).

Table 16. Output of the model for capital growth.

\begin{tabular}{|c|c|c|c|c|c|}
\hline Variables & Coefficient & S.E. & Wald & Sig. & Odds ratio \\
\hline AGEOWN & 1.387 & 1.218 & 1.296 & .255 & 4.001 \\
\hline EDUOWN & 2.466 & 1.423 & 3.001 & $.083 *$ & 11.775 \\
\hline ENTPTRAN & 1.265 & .978 & 1.674 & .196 & 3.543 \\
\hline EXPOWN & .311 & .943 & .109 & .742 & 1.364 \\
\hline MOTOWN & 2.454 & 1.354 & 3.286 & $.070 *$ & 11.631 \\
\hline LOCENT & .075 & .820 & .008 & .927 & 1.078 \\
\hline BUSPLAN & -.678 & 1.006 & .454 & .501 & .508 \\
\hline $\mathrm{ACCF}$ & -7.173 & 4.206 & 2.908 & $.088 *$ & .001 \\
\hline MKTLINKAGE & -.598 & 1.070 & .313 & .576 & .550 \\
\hline ACCBDS & 3.613 & 1.428 & 6.405 & $.011 * *$ & 37.081 \\
\hline $\mathrm{ACCW}$ & -1.086 & 1.005 & 1.169 & .280 & .337 \\
\hline $\mathrm{ACCT}$ & -2.130 & 3.321 & .411 & .521 & .119 \\
\hline NGOSUPP & -1.434 & 1.142 & 1.577 & .209 & .238 \\
\hline NUMOWN & 4.921 & 2.376 & 4.289 & $.038 * *$ & 137.114 \\
\hline STARTCAP & -.523 & .573 & .833 & .361 & .593 \\
\hline SOCIALNTWK & 6.188 & 2.458 & 6.337 & $.012 * *$ & 486.656 \\
\hline Constant & 2.643 & 4.841 & .298 & .585 & 14.053 \\
\hline -2 Log likelihood Ratio & & & & 53.7 & \\
\hline Chi-square $\left(\chi^{2}\right)$ & & & & 70.1 & \\
\hline Correctly predicted overall sample & & & & 92 & \\
\hline Correctly predicted growing (\%) & & & & 87 & \\
\hline Correctly predicted non-growing (\%) & & & & 94 & \\
\hline Pseudo R2 & & & & 71 & \\
\hline Sample size & & & & 100 & \\
\hline
\end{tabular}

Source: Survey result, $2016 .{ }^{*}, * * \& * * *$ indicates significant at $10 \% 5 \%$ \& $1 \%$.

Table 17. Output of the model for employment growth.

\begin{tabular}{|c|c|c|c|c|c|}
\hline Variable & Coefficient & S.E. & Wald & Sig. & Odds ratio \\
\hline AGEOWN & -1.689 & 1.062 & 2.527 & .112 & .185 \\
\hline EDUOWN & .518 & .997 & .270 & .604 & 1.678 \\
\hline ENTPTRAN & -2.171 & 1.211 & 3.217 & $.073 *$ & .114 \\
\hline EXPOWN & 1.028 & 1.120 & .843 & .358 & 2.796 \\
\hline MOTOWN & 2.471 & 1.260 & 3.846 & $.050 * *$ & 11.830 \\
\hline LOCENT & 3.006 & 1.093 & 7.561 & $.006 * *$ & 20.207 \\
\hline BUSPLAN & .954 & 1.512 & .399 & .528 & 2.597 \\
\hline $\mathrm{ACCF}$ & -5.987 & 1.962 & 9.312 & $.002 * *$ & .003 \\
\hline MKTLINKAGE & 4.137 & 1.250 & 10.957 & $.001 * * *$ & 62.645 \\
\hline ACCBDS & .823 & .953 & .745 & .388 & 2.277 \\
\hline $\mathrm{ACCW}$ & 2.752 & 1.321 & 4.341 & $.037 * *$ & 15.671 \\
\hline $\mathrm{ACCT}$ & 2.978 & 1.900 & 2.457 & .117 & 19.640 \\
\hline NGOSUPP & 1.109 & 1.203 & .849 & .357 & 3.031 \\
\hline Members & .132 & 1.243 & .011 & .916 & 1.141 \\
\hline STARTCAP & 1.186 & .734 & 2.613 & .106 & 3.274 \\
\hline SOCIALNTWK & 2.387 & 1.935 & 1.521 & .218 & 10.876 \\
\hline Constant & -9.679 & 3.578 & 7.319 & .007 & .000 \\
\hline -2 Log likelihood Ratio & & & & & 51 \\
\hline Chi-square $\left(\chi^{2}\right)$ & & & & & 82.9 \\
\hline Correctly predicted overall sample & & & & & 91 \\
\hline Correctly predicted growing (\%) & & & & & 87.5 \\
\hline Correctly predicted non-growing (\%) & & & & & 93.3 \\
\hline Pseudo $\mathrm{R}^{2}$ & & & & & 76.2 \\
\hline Sample size & & & & & 100 \\
\hline
\end{tabular}

Source: Survey result, 2016. ${ }^{*}, * * \& * * *$ indicates significant at $10 \% 5 \% \& 1 \%$. 


\subsubsection{Interpretation of Econometric Results}

As output of the binary logistic model indicates 10 explanatory variables are significantly affecting the probability of MSEs growth. Whereas the rest 9 of the 19 explanatory variables were found to have no significant influence on MSEs growth. The effect of the significant explanatory variables on MSEs growth in study area is discussed below.

Education level of MSE owners (EDUOWN): Education was found positively and significantly influences the probability of MSEs capital growth at less than $10 \%$ significance level. The odds ratio for the variable education is 11.7 which indicate that keeping the influence of other factors constant; the probability of MSEs growth for MSEs which had owners with education level 12 completed and above is 11.7 times higher than those MSEs with education level under 12 grade. However, as the model result shows for employment growth, education was found insignificant for MSEs employment growth. This is inconsistent with the finding of Garoma [17] who concluded that education matters when considering success from the point of employment growth rates. Since education level of owners influence capital growth of MSEs. We accept the second hypothesis 'Education levels of owners of MSEs and growth of MSEs have a positive relationship'.

Motivation of Owner (MOTOW): Motivation of owner found significant for both indicators employment and capital growth at 5\% and $10 \%$ significance level respectively. The odds ratio of motivation for capital growth is 11.63 indicating that, other things being constant, probability of capital growth for MSEs who have owners that joined MSE by choice is 11.63 times higher than those who joined by lack of alternative. The odds ratio of motivation for employment growth is 11.83 indicating that, other things being constant, probability of being growing in terms of employment growth for MSEs who have owners that joined MSE by choice is 11.83 times higher than those who joined by lack of alternative. Therefore we accept the fourth hypothesis' owners start business with entrepreneur vision /by choice has better opportunity to grow compared with owners start because of lack of alternative'. This confirms finding of Block and Sandner [19] found that being an entrepreneur out of necessity or opportunity driven motives have significant impact on growth.

Entrepreneurship training of MSE owners (ENTPTRAN): Econometric result of this study shows that there is significant and negative relation between employment growth and owner entrepreneurship training at less than $10 \%$ significance level. The probability of MSEs employment growth for MSEs which had owners taken entrepreneurship training, decreases by $11 \%$ than MSEs which had not taken entrepreneurship training. Therefore we reject the hypothesis' Entrepreneurship training has a positive relationship with MSEs growth of MSEs'. Previous studies of Andualem and others [23] and Garoma [17] found that there is no significant association between Entrepreneurial character of the owner and growth of MSEs.

Location Of enterprise (LOCENT): It was found that location of enterprise had a positive and significant influence on employment growth of MSEs. And it has also insignificant influence on capital growth. Holding other factors constant, probability of MSEs being growing for MSEs operate near to the main road/busy street is 20.2 $(\mathrm{P}<0.05)$ times higher than those MSEs operate out of the main road/busy street. Therefore we accept hypothesis 'MSEs that are operating at main roadside (busy street) have higher probability of growth as compared to those MSEs that are operating at outside the main roads'. This result confirms the findings of Eshetu\&Mammo, [20]; Gebreyesus [9] and McPherson, [24]. It is inconsistent with the findings of Habtamu [8] in Mekele city who found that MSEs that are operating at outside have higher probability of growth as compared to those MSEs that are operating at the main roads main roadside (busy street).

Initial Employment Size (INTIALEMPLOY): initial employment size of MSEs negatively and significantly affects probability of MSEs capital growth at less than 5\% significance level. The odds ratio for initial employment is 0.008 , which indicates that keeping other factors constant, a unit change in employment size; decrease the probability of MSEs capital growth by $8 \%$.This negative relation indicate that initially MSEs which had few employee hire more and more employee through time when their business become strong or expand very well. But if initially MSEs employee large number of employee they can be enough for the business at expansion time. Based on this, we accept the hypothesis 'MSEs start with small size of initial employment have higher probability of growth than those who start large employment size'.

Number of MSE owners: It was found that number of owners positively and significantly affects MSEs capital growth at less than 5\% significance level. The odds ratio for number of MES owners is 137.11 which indicate that a unit change of number of MSE owner increases the probability of MSE's capital growth 137.11 times. This is might be when the number of owner increases, the spirit of belongingness and the need to increase the dividend is very high. As a result every member of owner perform as much as he/she can. Therefore we reject the hypothesis "when the number of MSE owners increase the probability of MSEs growth decreases

Access to BDS (ACCBDS): It was found that access to BDS has positive and significant influence in MSEs capital growth at less than 5\% significance level. The odds ratio for capital growth is 37.08 which indicates that holding other factors constant, probability of MSEs being growing for MSEs which had access to BDS is 37.08 times higher than those who have no access to BDS. Based on this, we can accept hypothesis 'The probability of MSEs being growing is higher for MSEs who have access to BDS compared with those who have no access'.

Market Linkage (MKTLINKAGE): It was found that 
market linkage positively influences probability of MSEs employment growth at $1 \%$ significance level. The odds ratio for employment growth is 62.45 , this indicate that keeping other factors constant, the probability of MSEs being growing for MSEs which had access to market linkage is 62.45 times higher than those MSEs who have no access to market linkage.

Access to water (ACCW): The model output shows that access to water positively and significantly influence the employment growth of MSEs at 5\% significance level. Holding other factors constant, the probability of MSEs being growing for those MSEs which have access to water is 15 ( $\mathrm{p}<0.05)$ times higher than those MSEs who have no access to water. Based on this, we accept hypothesis 'Lack of infrastructure negatively affects growth of MSEs'. This result go along with the finding of Belay and others [25] and Habtamu [8].

Social Network (SOCIALNTWK): At less than 5\% significance level, social network has positive and significant influence on probability of MSE's capital growth. The odds ratio for the variable social network is 486 indicating that, holding other factors constant, the probability of capital growth for MSEs who have strong social network is 486 times higher than those MSEs who have no social network. This confirms the study of Garoma [17] and Adualem [23].

\section{Conclusion and Recommendations}

MSE is one of the institutions given recognition in Ethiopia's industry development plan and it considered as vehicles for employment opportunities at urban center and as it underpin the economic development. MSE serves as sources for sustainable job opportunities. Thus they should be given prior attention as they are important and serve for sustainable source of job opportunities to our country. They will also be the major productive forces in the manufacturing sectors when effort towards the country's renaissance is over. The promotion of MSEs is one of the strategic directions pursued by the government during the GTP implementation period (2010/11-2014/15), focusing on promoting the development and competitiveness of MSEs.

This study tried to identify factors that influence the growth of MSEs. Measuring the growth of MSEs is not a simple task since it is a vast and complex. In this specific study factors that influence capital and employment growth were identified. Based on these the following recommendations are forwarded.

Education level of MSE owners had significant influence on growth of MSEs. Therefore, at the establishment of MSEs education level should be given consideration. Market linkage has a great role on growth of MSEs andit was found significant at less than $1 \%$. Market linkage should be created for all sectors. The study shows that MSEs operate in construction sector have more access to market linkage but very little market linkage is created for other sectors. Even the frequency of market linkage created for construction sector is very small. MSEs will have more motivation to work when they have network with input suppliers and buyers.

Motivation of owner is found significant for both employment and capital growth. Most enterprises became unsuccessful because they are not interested in their work. They join MSEs at last when they unable to get any alternative. They are not ready to perform their activity by their own interest. As the study result shows MSE owners joined MSEs by their own choice regardless of other alternatives perform well. Growth rate for MSEs with owners who joined by choice is higher than those joined because of lack of alternative. Therefore the government body who concerned on establishment of MSEs should give serious attention on motivation of owner. Therefore, before establishing MSEs awareness creation should be done.

Entrepreneurship training needs further research. MSE owners who had access to entrepreneurship training should use the opportunity to perform well. Almost all of MSEs responded that they have access to finance. This is very interesting thing since access to finance is very crucial in growth of MSEs. This should be continued in this manner. As some interview made with MSES owners reveals that, even though most MSEs have access to finance they are not using this opportunity. This also needs serious attention. MSEs need to use available access of finance to expand their business. Micro financial institutions and Bureau of Trade and Industry office expected to create awareness to existing MSEs and newly established MSEs.

Access to business development service is very crucial for MSEs growth. MSEs need business development service. Therefore, facilitating the availability of BDS providers and follow up should be done by government and other institutions.

The other thing need consideration is infrastructure facility. Except transportation facility, MSEs face challenge on power supply and water supply. Power supply and water supply have significant effect on growth of MSEs. Therefore fulfilling infrastructure facility should be taken as an assignment. Almost all MSEs had social network. It needs support to expand their social network and make it strong. Government is providing working place for MSEs. This needs an appreciation. Some of MSES work on government constructed market shelter; others work on their own home. MSEs faced problem of working place they have no enough space. Even though there is good progress in provision of working place still it needs attention.

\section{References}

[1] Mammo, M. 2008. Network of Ethiopian Scholars (NES). Commentary No. 17

[2] Central Statistical Agency. 2010. Population and Housing Census in Ethiopia, Addis Ababa, 2010.

[3] Ermias Werkilul. 2011. A study on financial sources of micro and small enterprises in Addis Ababa (The Case of Gulelle Sub-City). MA thesis in business administration. Addis Ababa University. 
[4] MSE development strategy. 2011. Micro and small enterprises sector development yearly statistical bulletin. Addis Ababa, Ethiopia.

[5] Central Statistical Agency. 2007. Population and Housing Census in Ethiopia, Addis Ababa, 2007

[6] Ikechukwu, D. 2013. Re-defending youth leadership and Government. Presented at world youth Alliance conference $21^{\text {nd }}-23^{\text {th }}$ New York city, USA

[7] Seyum Menda. 2015. The Role of micro and small scale business enterprises in urban poverty alleviation: A Case study on cobble stone paving sector in Addis Ababa City. Thesis Submitted to Addis Ababa University

[8] HabtamuTefra, Aregawi Gebbremichael and Nigus Abera. 2013. Growth Determinants of micro and Small Enterprises: Evidence from Northern Ethiopia. Journal of Economics and Sustainable Development, 4(9), 128-135.

[9] Gebreeyesus, M. 2009. Innovation and micro-enterprises growth in Ethiopia: United Nation University. World Institute for Development Economics Research, 2009. ISSN 18102611.

[10] Wasihun. R and Paul, I. 2010. Growth determinants of women operated micro and small enterprises in Addis Ababa. Journal of Sustainable Development in Africa, 2010, Vol. 12, No. 6, p. 233-246. ISSN 1520-5509.

[11] Tassewwoldehanna, Wolday Amha and Manex Bulehelen. 2015. Business survival and the associated factors: empirical evidence from youth-owned micro and small enterprises in Ethiopia.

[12] Baum, J., Locke, E., and Smith, K. 2001. A multidimensional model of venture growth. Academy of Management Journal, 44 (2), 292-303.

[13] Holmes and Zimmer. 1994. The nature of small firm. Australian Journal of Management, Vol. 19, No. 1. ISSN 0266-2426.

[14] Evans, D. 1987. Test of alternative theories of firm growth. Journal of Political Economics, 1987, Vol. 95, No. 4, p. 65774. ISSN 0022-3808.

[15] Cheng, R. W. 2006. Determinants of growth in small and medium enterprise. An empirical study on logistic industry in Hongkong. Doctorial thesis. Curtin University of Technology.
[16] Amran, N. A. 2011. The Effect of owner's gender and age to firm performance: A Review on Malaysian Public Listed Family Businesses. Journal of Global Business and Economics 2 (1): 104-116.

[17] Garoma, B. F. 2012. Determinants of microenterprise success in the urban informal sector of Addis D Ababa: phd, Erasmus University Rotterdam.

[18] Tassewwoldehanna, Wolday Amha and Manex Bulehelen. 2015. Business survival and the associated factors: empirical evidence from youth-owned micro and small enterprises in Ethiopia

[19] Block, J. and Sandner, P. 2009. Necessity and Opportunity Entrepreneurs and their Duration in Self-employment: Evidence from German Micro Data. Berlin: SOEP papers on Multidisciplinary Panel Data Research

[20] Eshetu, B and Mammo. M. 2009. Promoting micro, small and medium enterprises (MSMEs) for sustainable rural Livelihood. Development, Innovation and International Political Economy Research (DIIPER). Aalborg University, Denmark, 2009. ISSN 1902-8679.

[21] Siropolis, N. 1998. Entrepreneurship and small business management $\left(6^{\text {th }}\right.$ ed. $)$. Indian: All Indian publishers and distributors' regd.

[22] Gujarati, D. N. 2004. Basic Econometrics. (4th ed.). McGrawHill companies. New York, ISBN 978-0-07-233542-2

[23] Andualem Gezahegn, Shimelis Zewdie and Chalchissa Amentie. 2015. Factors determining the success of micro and small enterprises in Ethiopia (The Case of Arbaminch Town). Social and Business Science Review Volume 3 Pages: 69-76.

[24] McPherson. 1996. Growth of micro and small enterprises in South Africa. Journal of Development Economics, 1996, Vol. 48, p. 253-277. ISSN 0304-3878.

[25] Belay Kinati, Asmera Teshomeand TekalignMinalu. 2015. Factors affecting developments of micro and small Enterprises (Case of Mettu, Hurumu, Bedelle and Gore Towns of Ilu Aba Bora Administrative Zone) International Journal of Scientific and Research Publications, Volume 5, P (2250-3153). 